\title{
Metabolic Studies on Scorbutic Guinea Pigs
}

\section{CATABOLISM OF $\left[4 .{ }^{14} \mathrm{C}\right] \mathrm{CHOLESTEROL} \mathrm{IN} \mathrm{VIVO} \mathrm{AND} \mathrm{IN} \mathrm{VITRO*}$}

\author{
By RASHBIHARI GUCHHAIT, B. C. GUHA $\dagger$ AND N. C. GANGULI $\ddagger$ \\ Department of Applied Chemistry, University College of Science and Technology, Calcutta 9, India
}

(Received 24 May 1962)

Several reports have appeared on the effect of ascorbic acid deficiency on metabolic processes (Sealock \& Silberstein, 1940; Banerjee, Biswas \& Singh, 1958, 1959; Ganguli \& Roy, 1954; Ganguli \& Banerjee, 1961; Guchhait \& Ganguli, 1961 $a$; Banerjee \& Ganguli, 1962). The metabolism of cholesterol was found to be altered in scorbutic guinea pigs (Oesterling \& Long, 1951; Banerjee \& Deb, 1951; Belavady \& Banerjee, 1954; Guchhait \& Ganguli, 1960; Banerjee \& Singh, 1958). Oesterling \& Long (1951) and Banerjee \& Deb (1951) have reported a diminished concentration of adrenal cholesterol in scurvy. Belavady \& Banerjee (1954) observed that scorbutic guinea pigs excrete a smaller amount of injected $p$-aminobenzoic acid in the acetylated form and concluded that the decrease in the concentration of adrenal cholesterol in scurvy may be attributed to diminished acetylation in the body. Banerjee \& Singh (1958) have also indicated an increase in the total body cholesterol content in scorbutic guinea pigs compared with the normal controls. Prolonged treatment of the diseased animal with insulin lowered the cholesterol content to the normal value.

The experiments in vivo by Becker, Burch, Salomon, Venkitasubramanian \& King (1953) further showed that $\left[1-{ }^{14} \mathrm{C}\right]$ ascorbic acid is not appreciably incorporated into the cholesterol moiety, but that the ascorbic acid supplement to the diet exerted a marked effect on the conversion of $\left[1-{ }^{14} \mathrm{C}\right]$ acetate into cholesterol and other steroids in the guinea pig. They found that scorbutic guinea pigs incorporated six times as much radioactivity from $\left[1-{ }^{14} \mathrm{C}\right]$ acetate into cholesterol isolated from the adrenals compared with the control fed ad libitum. Bolker et al. (1956), on the other hand, reported that, although the concentration of serum cholesterol of scorbutic guinea pigs was significantly elevated, the rates of incorporation of $\left[1-{ }^{14} \mathrm{C}\right]$ acetate into cholesterol and fatty acids by liver, aorta and adrenal slices were not affected in

* Part 2: Banerjee \& Ganguli (1962).

$\uparrow$ Deceased 20 March 1962.

$\ddagger$ Present address: National Dairy Research Institute, Karnal, India. scurvy. An increased hepatic synthesis of cholesterol from both $\left[1{ }^{14} \mathrm{C}\right]$ acetate and $\left[2-{ }^{14} \mathrm{C}\right]$ acetate by scorbutic guinea pigs was reported by Guchhait \& Ganguli (1960).

The apparent increase in the synthesis of cholesterol in seurvy may also be due to the depressed utilization of the synthesized cholesterol by the scorbutic animal. With a decreased turnover of liver cholesterol one might expect to find an increase in the cholesterol content. A study of the catabolism of cholesterol to bile acids in scurvy was therefore undertaken to investigate this possibility. The present paper deals with the conversions in vivo and in vitro of $\left[4-{ }^{14} \mathrm{C}\right]$ cholesterol into bile acids by scorbutic guinea pigs. Hypercholesterolaemia in scurvy seems to be due not only to an increased cholesterol synthesis but also to a depressed catabolism of cholesterol.

\section{EXPERIMENTAL}

Materials. $\left[{ }^{4-14} \mathrm{C}\right]$ Cholesterol was purchased from The Radiochemical Centre, Amersham, Bucks.; NAD, crystalline bovine serum albumin and tris were products from the Sigma Chemical Co., St Louis, Mo., U.S.A.; AMP was obtained from Schwartz Laboratories, Mount Vernon, N.Y., U.S.A.

Treatment of animals. Male guinea pigs, weighing 250$300 \mathrm{~g}$., were maintained on a diet consisting of green grass, Bengal gram (water-soaked) and the scorbutogenic diet (Banerjee, 1945) for 5 days. Animals which grew well were selected and separated into several groups, each group consisting of one pair-fed and one scorbutic guinea pig. All the animals were then maintained on the scorbutogenic diet. The pair-feeding technique followed was as reported by Ganguli \& Banerjee (1961). The pair-fed control was also given $5 \mathrm{mg}$. of ascorbic acid daily. All the animals were given 2 drops of a concentrate of vitamins $A$ and $D$ twice a week. The animals were killed, usually during the fourth week, when the scorbutic group developed severe symptoms of the disease. The experiments with the scorbutic and the pair-fed animals were performed on two consecutive days.

Preparation of cholesterol suspension. A solution of $5 \mathrm{mg}$. of cholesterol (purified over alkaline alumina) in $0.5 \mathrm{ml}$. of ethanol was added slowly with constant stirring to $5 \mathrm{ml}$. of aq. $1 \%(w / v)$ crystalline bovine serum albumin solution at $40^{\circ}$ (Horning, Fredrickson \& Anfinsen, 1957). The ethanol was removed from the suspension under vacuum and was bubbled with nitrogen to ensure an anaerobic atmosphere

Bioch. 1963, 86 
before being stored. The stabilized suspension was stored at $-15^{\circ}$ and it remained uniform in appearance for several months. It was thoroughly stirred before use.

Preparation of heat-stable soluble cofactor for studies in vitro. The definite role of the soluble fraction from boiled liver extract in cholesterol catabolism has been emphasized by several workers (Anfinsen \& Horning, 1953; Lynn, Staple \& Gurin, 1955). Therefore the heat-stable soluble fraction was prepared from the respective animal liver by the method of Horning et al. (1957). An aqueous homogenate of liver tissue $\left(2.5 \mathrm{ml} . / \mathrm{g}\right.$.) was heated at $90-95^{\circ}$ for 5 min. and the precipitated protein was removed by centrifuging at $20000 \mathrm{~g}$ for $40 \mathrm{~min}$. at $2^{\circ}$. The straw-coloured supernatant was used in the studies in vitro. The soluble fraction was always freshly prepared from each animal for use in the various studies.

Experiments in vivo. When the experimental animal became severely scorbutic, $5 \mu \mathrm{O}$ of [4-14 C]cholesterol, having 5740 counts/min., was injected intraperitoneally into each animal, both scorbutic and pair-fed control. The animals were then kept in separate metabolism cages to collect the faeces. After $24 \mathrm{hr}$. the animals were killed, and liver and gall-bladder fluid were immediately collected. Faeces, liver and bile were then analysed for the distribution of radioactive cholesterol and bile acids.

Studies with liver mitochondria in vitro. Liver mitochondria were prepared by the method of Hogeboom (1955), as described by Guchhait \& Ganguli (1961 b). The incubation was carried out in a specially designed $50 \mathrm{ml}$. flask with a central well and a rubber stopper as described by Katz \& Chaikoff (1954). The central well contained $0.5 \mathrm{ml}$. of $20 \%$ (w/v) $\mathrm{KOH}$ to absorb the respired carbon dioxide. The main compartment of each flask contained the following components, the cofactor additions being as described by Horning et al. (1957): $100 \mu \mathrm{moles}$ of tris buffer, pH 8.5, 2.5 $\mu$ moles of NAD, $10 \mu$ moles of AMP, $100 \mu$ moles of nicotinamide, $20 \mu$ moles of cysteine (instead of glutathione), $1 \mathrm{ml}$. of the soluble fraction from the appropriate animal, $0.5 \mathrm{mg}$. of unlabelled cholesterol suspension, $8.5 \mu \mathrm{g}$. of $\left[4^{-14} \mathrm{C}\right]$ cholesterol containing $5.7 \times 10^{5}$ counts/min. and $2 \mathrm{ml}$. of a liver-mitochondria suspension $(1: 2)$ as the enzyme source. Generally $2.5-3.5 \mathrm{mg}$. of mitochondrial nitrogen was used in each flask. The total volume of the reaction mixture was $5 \mathrm{ml}$. The flasks were stoppered with rubber caps and placed, with constant shaking, in a water bath at $37^{\circ}$ for $3 \mathrm{hr}$. After incubation the reaction was stopped by injecting $4 \mathrm{vol}$. of ethanol into the main compartment of the flask through the rubber stopper.
Analytical methods. The saponification of the bile from the gall bladder, liver tissue, faeces or incubation mixture, subsequent extraction of the non-saponifiable material, and the extraction of bile acids and fatty acids from the saponifiable fractions, were carried out according to the methods of Danielsson \& Kazuno (1959) and Siperstein, Jayko, Chaikoff \& Dauben (1952). The nitrogen content of the mitochondria was estimated by the micro-Kjeldahl method of Ma \& Zuazaga (1942). Cholesterol was precipitated as the digitonide (Sperry \& Webb, 1950).

Radioactivity measurements. Cholesterol was plated as the digitonide from an ethereal suspension and bile acids as the ammonium salts in an ethanolic solution on stainless-steel planchets. Plating was made as uniform and with as thin a layer as possible. The radioactivity measurements were done as described by Ganguli \& Banerjee (1961). A windowless gas-flow counter (Nuclear-Chicago Corp.) was used for counting, and corrections were made for self-absorption and background. The counting of each sample was performed at least in triplicate.

\section{RESULTS}

\section{Studies in vivo}

Catabolism of $\left[4-{ }^{14} \mathrm{C}\right]$ cholesterol in the liver of scorbutic guinea pigs. The results on the catabolism in vivo of $\left[4-{ }^{14} \mathrm{C}\right]$ cholesterol to bile acids by the liver tissue of scorbutic guinea pigs are recorded in Table 1. A change in the rate of incorporation of cholesterol into bile acids is apparent. The formation of bile acids by the liver from cholesterol is depressed in the scorbutic guinea pigs compared with the pair-fed controls. On the other hand, the non-saponifiable fraction (containing cholesterol) from the scorbutic guinea-pig liver contains much more radioactivity than that from the liver of the pair-fed control. The results indicate that cholesterol is less effectively utilized for its conversion into bile acids in the liver of guinea pigs with scurvy.

Incorporation of $\left[4-{ }^{14} \mathrm{C}\right]$ cholesterol into bile acids of the gall bladder by scorbutic guinea pigs. Table 1 also shows values for the transformation of $\left[4{ }^{14} \mathrm{C}\right]$ cholesterol into bile acids present in the gall bladder

Table 1. Cataboliom of $\left[4-{ }^{14} \mathrm{C}\right]$ cholesterol in the liver and gall bladder of scorbutic guinea pigs in vivo

The experimentel conditions are described in the text. The results are from six individual pairs of animals and are expressed in counts/min./g. of liver and gall-bladder bile.

\begin{tabular}{|c|c|c|c|c|}
\hline \multirow{3}{*}{$\begin{array}{l}\text { Condition of } \\
\text { animals }\end{array}$} & \multicolumn{4}{|c|}{$10^{-8} \times$ Radioactivity } \\
\hline & \multicolumn{2}{|c|}{ In bile acids } & \multicolumn{2}{|c|}{ In non-saponifiable fraction } \\
\hline & Range & Average & Range & Average \\
\hline Liver & & & & \\
\hline $\begin{array}{l}\text { Soorbutic } \\
\text { Pair-fed } \\
\text { Gall bladder }\end{array}$ & $\begin{array}{l}1 \cdot 12-1 \cdot 18 \\
2 \cdot 81-3 \cdot 23\end{array}$ & $\begin{array}{l}1 \cdot 16 \\
2 \cdot 90\end{array}$ & $\begin{array}{l}80 \cdot 24-84 \cdot 25 \\
20 \cdot 28-22 \cdot 56\end{array}$ & $\begin{array}{l}83.56 \\
20.58\end{array}$ \\
\hline $\begin{array}{l}\text { Scorbutic } \\
\text { Pair-fed }\end{array}$ & $\begin{array}{l}10 \cdot 12-11 \cdot 02 \\
\mathbf{4 0 . 6 5 - 4 4 . 8 7}\end{array}$ & $\begin{array}{l}10 \cdot 05 \\
43 \cdot 18\end{array}$ & $\begin{array}{l}33 \cdot 44-41 \cdot 12 \\
13 \cdot 33-16 \cdot 98\end{array}$ & $\begin{array}{l}39 \cdot 93 \\
15 \cdot 33\end{array}$ \\
\hline
\end{tabular}


Table 2. Incorporation of $[4-14 \mathrm{C}]$ cholesterol in vivo into bile acids found in the intestine of scorbutic guinea pigs

The experimental conditions were as in Table 1 . The results are expressed as total counts/min. present in the intestinal washings and faeces and from six individual animals.

$\begin{array}{llccc}\text { Condition of } \\ \begin{array}{c}\text { animals } \\ \text { Scorbutic }\end{array} & \overbrace{\text { Range }}^{\text {In bile acids }} & \text { Average } & \overbrace{\text { Range }}^{10^{-3} \times \text { Radioactivity }} & \text { Average } \\ \text { Pair-fed } & 28 \cdot 00-29 \cdot 80 & 29 \cdot 28 & 3360-3368 \cdot 67 & 3362 \cdot 00 \\ 40 \cdot 67-42 \cdot 66 & 41 \cdot 31 & 220 \cdot 00-250 \cdot 50 & 244 \cdot 00\end{array}$

Table 3. Effect of ascorbic acid on the conversion of $\left[4-{ }^{14} \mathrm{C}\right]$ cholesterol into bile acids by liver mitochondria from scorbutic guinea pigs in vitro

The experimental conditions are described in the text. Ascorbic acid was neutralized just before use. Results for the complete system are ranges for six experiments and for the others the means of two experiments.

\begin{tabular}{|c|c|c|c|c|}
\hline \multirow[b]{3}{*}{ System } & \multicolumn{4}{|c|}{ Radioactivity incorporated by liver mitochondria } \\
\hline & \multicolumn{2}{|c|}{ In scorbutic animals } & \multicolumn{2}{|c|}{ In pair-fed controls } \\
\hline & $\begin{array}{c}\text { Total } \\
\text { counts/min. }\end{array}$ & $\begin{array}{l}\text { Counts/min. } / \mathrm{mg} . \\
\text { of } \mathrm{N}\end{array}$ & $\begin{array}{c}\text { Total } \\
\text { counts/min. }\end{array}$ & $\underset{\text { of } \mathrm{N}}{\text { Counts/min. }} / \mathrm{mg}$. \\
\hline Complete & $6230-6244$ & $2500-2578$ & $8833-8867$ & 3223-3275 \\
\hline $\begin{array}{l}\text { Complete }+0.5 \mathrm{mg} \text {. of } \\
\text { ascorbic acid }\end{array}$ & 7631 & 3114 & 9475 & 3484 \\
\hline $\begin{array}{l}\text { Complete }+1.0 \mathrm{mg} . \text { of } \\
\text { ascorbic acid }\end{array}$ & 8485 & 3463 & 10320 & 3794 \\
\hline
\end{tabular}

of scorbutic and pair-fed guinea pigs. In the scorbutic animals it seems that there was, as in liver, less incorporation of ${ }^{14} \mathrm{C}$ into the bile acids in the gall bladder, whereas the non-saponifiable fraction contained more of the injected cholesterol radioactivity.

Effect of scurvy on the formation of bile acids from [4-14 $\mathrm{C}]$ cholesterol in the intestine. The radioactivity present in the bile acids of the intestine and faeces in scorbutic guinea pigs is presented in Table 2. Results indicate that, as with the liver and gallbladder bile, the intestine and faeces from the scorbutic guinea pigs also contained a smaller quantity of radioactivity in bile acids compared with the pair-fed controls. Table 2 also shows that the non-saponifiable fraction contained the major portion of the radioactivity when compared with either the liver or the bladder bile.

\section{Studies in vitro}

Incorporation of $\left[4-{ }^{14} \mathrm{C}\right]$ cholesterol into bile acids by liver mitochondria from scorbutic guinea pigs. The incorporation of $\left[4-{ }^{14} \mathrm{C}\right]$ cholesterol into bile acids by the liver-mitochondrial preparation from the scorbutic guinea pigs is shown in Table 3. Liver mitochondria from the scorbutic guinea pigs converted less cholesterol into bile acids than did the preparation from the pair-fed animals; this depressed formation was apparent even on a mitochondrial-nitrogen basis.

Effect of ascorbic aicid on the conversion of [4-14 $\mathrm{C}]$ cholesterol into bile acids by liver mitochondria from scorbutic guinea pigs. Table 3 shows the effect of added ascorbic acid on the conversion of cholesterol into bile acids in vitro by liver mitochondria from scorbutic guinea pigs. Ascorbic acid stimulated the depressed rate of transformation in the preparations from scorbutic animals, and also had an enhancing effect on the preparations from the pairfed controls. These results, therefore, indicate that the catabolism of cholesterol to bile acids is probably dependent on ascorbic acid in scorbutic guinea pigs.

\section{DISCUSSION}

It is well known that cholesterol is the metabolic precursor for the formation of bile acids in living organisms. The production of bile acids by liver tissue appears to be the major pathway of cholesterol catabolism in higher animals. This transformation occurs through the oxidation of the side chain followed by hydroxylation of the ring structure of the cholesterol moiety (Siperstein \& Chaikoff, 1955; Bergstrom \& Bergstrom, 1956; Freidman, Byers \& St George, 1956; Kritchevsky, 1958; Gould, 1958). 
Our results indicate that the injected cholesterol was not metabolized to the same extent to bile acids in the scorbutic guinea pigs compared with the pair-fed controls. The incorporation into the bile acid fraction of liver tissue, gall bladder (Table 1) or intestinal fluid with faeces (Table 2) was depressed in scurvy. This disturbance in cholesterol catabolism would result in a slower utilization, and thereby an increased concentration, of the cholesterol reserve in tissues in this disease (Banerjee \& Singh, 1958). However, an increased synthesis of cholesterol from $\left[1 \cdot{ }^{14} \mathrm{C}\right]$ acetate or $\left[2-{ }^{14} \mathrm{C}\right]$ acetate by the scorbutic-guinea-pig liver was also observed in vitro by Guchhait \& Ganguli (1960) and in vivo by Becker et al. (1953).

From the studies in vitro with liver mitochondria of scorbutic guinea pigs (Table 3), the depressed incorporation into the bile acid fraction again indicates that the transformation of cholesterol into bile acids is disturbed. The demonstration of the enhancement of this conversion by added ascorbic acid in the system (Table 3) gives a clearer picture of the role of ascorbic acid in this catabolic process. From the present observations it is difficult to assess whether ascorbic acid is helping the breakdown of the side chain in addition to the hydroxylation of the sterol moiety. This can only be verified with cholesterol labelled in the side chain, which gives rise to carbon dioxide, and this has not been examined. Information on this point would be especially important in evaluating the relevance of the present observations in scurvy. A disturbance in the hydroxylation would be more likely, as ascorbic acid is known to influence hydroxylations such as the proline-hydroxyproline transformation (Gould \& Woessner, 1957). The results from the addition of ascorbic acid in vitro seem to further strengthen this hypothesis.

It is, therefore, conceivable that the increased body content of cholesterol in scurvy cannot entirely be attributed to the greater rate of cholesterol synthesis (Guchhait \& Ganguli, 1960; Becker et al. 1953), although more acetate may become available owing to a disturbance of the Krebs cycle (Guchhait \& Ganguli, 1961a). We believe the present findings indicate that in scurvy there is decreased cholesterol catabolism. Evidence was also presented by Whitehouse, Staple \& Gurin (1959) that the oxidation of the terminal methyl group of cholesterol requires the functioning of the Krebs cycle, and therefore in scurvy one can expect a depressed catabolism of cholesterol as the operation of the Krebs cycle is disturbed in this disease (Banerjee et al. 1959; Ganguli \& Banerjee, 1961). Thus, in scurvy, there may be an increased synthesis coupled with a decreased catabolism of cholesterol, resulting in an accumulation of cholesterol.

\section{SUMMARY}

1. The incorporation of $\left[4-{ }^{-14} \mathrm{C}\right]$ cholesterol into the bile acid fraction was depressed in scorbutic guinea pigs in vivo. Both in the liver and in the gall-bladder bile from scorbutic guinea pigs the bile acid fraction had less radioactivity in it compared with that from the pair-fed animals after the injection of $\left[4^{-14} \mathrm{C}\right]$ cholesterol.

2. A diminished incorporation of $\left[4^{-14} \mathrm{C}\right]$ cholesterol into bile acids in the faeces and intestinal washings was observed in scorbutic guinea pigs. A greater excretion of radioactive cholesterol by these scorbutic animals was also observed.

3. The catabolism of $\left[4-{ }^{14} \mathrm{C}\right]$ cholesterol in vitro also indicated a diminished conversion of cholesterol into the bile acid fraction by liver mitochondria from scorbutic guinea pigs.

4. The addition of ascorbic acid in vitro enhanced the formation of bile acids from $\left[4^{-14} \mathrm{C}\right]-$ cholesterol by mitochondrial preparations from livers of both scorbutic and pair-fed guinea pigs. The stimulating effect of ascorbic acid was more prominent with the mitochondria from the scorbutic animals than with those from the controls.

One of us (R.G.) is grateful to the Ministry of Education, Government of India, for a scholarship during this work.

\section{REFERENCES}

Anfinsen, C. B. \& Horning, M. G. (1953). J. Amer. chem. Soc. 75, 1511.

Banerjee, S. (1945). J. biol. Chem. 159, 327.

Banerjee, S., Biswas, D. K. \& Singh, H. D. (1958). J. biol. Chem. 230, 261.

Banerjee, S., Biswas, D. K. \& Singh, H. D. (1959). J. biol. Chem. 234, 405.

Banerjee, S. \& Deb, C. (1951). J. biol. Chem. 190, 177.

Banerjee, A. B. \& Ganguli, N. C. (1962). J. biol. Chem. 237, 14.

Banerjee, S. \& Singh, H. D. (1958). J. biol. Chem. 233, 336.

Becker, A. R., Burch, H. B., Salomon, L. L., Venkitasubramanian, T. A. \& King, C. G. (1953). J. Amer. chem. Soc. 75, 2020.

Belavady, B. \& Banerjee, S. (1954). J. biol. Chem. 209, 641.

Bergstrom, S. \& Bergstrom, B. (1956). Annu. Rev. Biochem. 25, 177.

Bolker, R. E., Fishman, S., Heard, R. D. H., O'Donnell, V. J., Webb, J. L. \& Willis, G. C. (1956). J. exp. Med. $103,199$.

Danielsson, H. \& Kazuno, T. (1959). Acta chem. scand. 13, 1137.

Freidman, M., Byers, S. O. \& St George, S. (1956). Annu. Rev. Biochem. 25, 613.

Ganguli, N. C. \& Banerjee, A. B. (1961). J. biol. Chem. 236, 979.

Ganguli, N. C. \& Roy, S. C. (1954). Ann. Biochem. 14, 35. Gould, B. S. \& Woessner, J. F. (1957). J. biol. Chem. 226, 289.

Gould, R. G. (1958). In Cholesterol, p. 283. Ed. by Cook, R. P. New York: Academic Press Inc. 
Guchhait, R. \& Ganguli, N. C. (1960). Abstr. Symp. Biochemical Aspects of Cholesterol Metabolism and Atherosclerosis, p. 8.

Guchhait, R. \& Ganguli, N. C. (1961a). Biochim. biophys. Acta, 51, 607.

Guchhait, R. \& Ganguli, N. C. (1961b). J. sci. industr. Res. $20 \mathrm{C}, 195$.

Hogeboom, G. H. (1955). In Methods in Enzymology, vol. 1, p. 16. Ed. by Colowick, S. P. \& Kaplan, N. O. New York: Academic Press Inc.

Horning, M. G., Fredrickson, D. S. \& Anfinsen, C. B. (1957). Arch. Biochem. Biophys. 71, 266.

Katz, J. \& Chaikoff, I. L. (1954). J. biol. Chem. 206, 887.

Kritchevsky, D. (1958). In Cholesterol, p. 115. New York: John Wiley and Sons. Inc.
Lynn, W. S., Staple, E. \& Gurin, S. (1955). Fed. Proc. 14, 783.

Ma, T. S. \& Zuazaga, G. (1942). Industr. Engng Chem. (Anal.) 14, 280.

Oesterling, M. J. \& Long, G. N. H. (1951). Science, 113, 241.

Sealock, R. R. \& Silberstein, H. E. (1940). J. biol. C'hem. 135, 251.

Siperstein, M. D. \& Chaikoff, I. L. (1955). Fed. Proc. 14, 767.

Siperstein, M. D., Jayko, M. E., Chaikoff, I. L. \& Dauben, W. G. (1952). Proc. Soc. exp. Biol. N.Y., 81, 720.

Sperry, W. M. \& Webb, M. (1950). J. biol. Chem. 187, 97.

Whitehouse, M. W., Staple, E. \& Gurin, S. (1959). J. biol. Chem. 234, 276.

Biochem. J. (1963) 86, 197

\title{
The Catabolism of Proteins and Nucleic Acids in Starved Aerobacter aerogenes
}

\author{
By R. E. STRANGE, H. E. WADE AND A. G. NESS \\ Microbiological Research Establishment, Porton, Wilts.
}

(Received 7 June 1962)

Previous studies on the longevity of starved stationary-phase Aerobacter aerogenes indicated that, before the death of a significant proportion of the population, losses of substantial amounts of protein, RNA and (if initially present) glycogen occurred (Strange, Dark \& Ness, 1961; Strange, 1961). The analysis of the suspending fluid during starvation showed that ammonia, nucleic acid bases and inorganic phosphate had been released to an extent that suggested their origin from macromolecules.

There have been several reports of substantial losses of RNA from suspensions of starved viable bacteria (Borek, Ryan \& Rockenbach, 1955; Rotman, 1958; Holden, 1958) and yeasts (Higuchi \& Uemura, 1959). Since most of the RNA and a substantial fraction of the total protein are present in the ribosomes (Tissieres, Watson, Schlessinger \& Hollingworth, 1959), it appeared likely that the latter suffered these losses. To determine to what extent the total losses of RNA and protein could be accounted for in this way, the changes in compositions of sedimentation fractions from starved $A$. aerogenes were followed. In addition, the extent to which these losses could be accounted for by substances released into the suspending fluid was examined.

\section{MATERIALS AND METHODS}

Cultural conditions. Aerobacter aerogenes (N.C.T.C. 418), originally obtained from Professor Sir Cyril Hinshelwood's Laboratory, was grown either on tryptic meat broth, pre- pared from bullock's meat as described for Hartley's broth (Mackie \& McCartney, 1948) and diluted with water to give a concentration of $2.5 \mathrm{mg}$. of $\mathrm{N} / \mathrm{ml}$. or on a carbonlimiting defined medium $(11 \mathrm{~N})$, which contained $1 \%$ (w/v) of mannitol, prepared as described by Strange et al. (1961).

The bacteria were grown in 31 . of medium at $37^{\circ}$ with adequate aeration and at a controlled $\mathrm{pH}(\mathbf{7 \cdot 2 )}$ in the apparatus described by Strange et al. (1961). When growth, as determined by turbidity, had ceased for $0.5 \mathrm{hr}$. the bacteria were sedimented by centrifuging, washed with 20 vol. of buffered saline ( $0.02 \mathrm{M}$-potassium orthophosphate in $0.13 \mathrm{M}-\mathrm{NaCl}$ at $\mathrm{pH} 6.5$ ) and resuspended in the same solution (4-5 mg. dry wt. $/ \mathrm{ml}$., equivalent to $1 \times 10^{10_{-}}$ $2.5 \times 10^{10}$ viable bacteria $/ \mathrm{ml}$.).

Starvation. Suspensions of freshly harvested and washed bacteria were incubated at $37^{\circ}$ in a gas wash-bottle as described by Strange et al. (1961). A reflux water condenser, closed with a cotton-wool filter, was fitted to the outlet to prevent a volume change during starvation.

Viability. The viability was determined by two methods. The proportion of viable bacteria was determined directly by a slide culture technique (Postgate, Crumpton \& Hunter, 1961) in which the growth of viable bacteria on tryptic-meat-broth-agar is observed directly under a microscope by dark-ground illumination. The reproducibility of the method has been discussed previously (Postgate et al. 1961; Strange et al. 1961). The concentration of viable bacteria was determined by plate count on trypticmeat-broth-agar; the determination was carried out in duplicate and the coefficient of variation was about $\pm 6 \%$.

Sedimentation fractionation. A measured volume of bacterial suspension ( $280 \mathrm{ml}$.) was centrifuged at $11000 \mathrm{rev}$./ min. for $15 \mathrm{~min}$. in a MSE no. 13 angle centrifuge and the deposit was washed with a solution of $5 \mathrm{~mm}-\mathrm{MgCl}_{2}$ in 